\title{
BASICS ENGLISH GUARANTEE IN EFFORTS TO INCREASE THE ABILITY OF BIDIKMISI IAI AS'ADIYAH SENGKANG STUDENTS
}

\author{
Yusuf Razaq ${ }^{1^{*}}$ \\ Satriani ${ }^{2}$ \\ 1,2 Institut Agama Islam As'adiyah Sengkang, Sengkang, Indonesia \\ yusufrazaq@gmail.com ${ }^{1 *}$ \\ satrianiani200894@gmail.com $^{2)}$
}

Keywords: [Training, Basic English, Bidikmisi]

Published by:

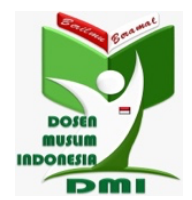

Copyright (C) 2021 The Author(s)

This article is licensed under CC BY 4.0 License (cc) $\mathrm{BY}$

https://dmi-journals.org/jai
Abstract: The quality of English instruction in Indonesia is not uniformly spread across the country. Those in big cities are more likely to receive qualified English instruction than students in rural areas. Bidikmisi kids do not have access to additional English learning resources, despite the fact that they require them. Finally, because English proficiency is so vital, their competition is low. As a result, Bidikmisi pupils' basic English skills must be enhanced in order to be more competitive. Basic English Training is provided to Bidikmisi students at IAI As'adiyah Sengkang who need it the most as part of this program. Aside from the pretest and post-test, 12 meetings were held. The results suggest that Bidikmisi students' basic English skills have improved. However, they must be persistent in their efforts to improve their knowledge in order to greatly boost their competency. It may be concluded that the basic English training program for Bidikmisi pupils aids in the development of human resource capabilities in the English field. 


\section{Introduction}

Bidikmisi students are chosen students from various parts of Indonesia who have a good academic background depending on their school, but poor economic abilities (Suryadarma \& Jones, 2013; Wasahua et al., 2018; Fadhil \& Sabic-El-Rayess, 2021). They are chosen from among a large number of students to pursue higher education with public funding. They should be able to break the cycle of poverty and even modify the environment around them to make it more competitive and capable. It is hoped that they will become change agents who have a significant impact on the environment, at least in their immediate families, and also on a national level. The missions of the Bidikmisi program are as follows:

1. Allowing people who are economically disadvantaged but have high academic potential to continue their education at a higher level;

2. Allowing underprivileged communities with high academic potential to become human resources with national values, patriotism, love for the country, and a spirit of defense to become human resources.

3. Provide chances for underserved groups with strong academic potential to contribute to the nation's competitiveness in a period of global competition, particularly in light of the ASEAN Economic Community (AEC), which has been ratified by all ASEAN countries (Direktorat Jenderal, 2017).

Teaching English, on the other hand, has not been equally disseminated throughout Indonesia (Pasassung, 2003; Zein, 2017; Mudra, 2018; Parlindungan et al., 2018; Solikhah \& Budiharso, 2019). Because of the many deficiencies faced by teachers, such as infrastructure, learning resources, language issues, parental thoughts, teacher shortages, and others, kids who study in big cities tend to receive better English instruction than students who study in remote locations (Lamb \& Coleman, 2008; Hadisantoso, 2010; Lamb, 2012; Lamb, 2013; Febriana et al., 2018; Solikhah \& Budiharso, 2019). This has an effect on these students' preparation for English lectures at universities; they typically begin with a weaker prefix than students from big cities, though this is not always the case. Furthermore, Bidikmisi students lack the financial ability to obtain 'extra learning' or access other language learning tools. Finally, it is anticipated that, despite their academic potential, their competitiveness would suffer as a result of their poor English abilities. This is due to the fact that English proficiency is one of the most significant criteria for competing for job prospects. As a result, in order to be more competitive, Bidikmisi students' basic English abilities, particularly those from outside of Sengkang, must be strengthened.

The key problems may be stated based on the circumstance analysis, namely:

1. Bidikmisi IAI's English ability Because they are not exposed to studying on par with those in big cities, the number of As'adiyah Sengkang students who come from outside the city is still low.

2. Due to their financial disadvantage, Bidikmisi pupils find it difficult to access additional English learning opportunities.

The aforementioned issues necessitate solutions. IAI As'adiyah Sengkang's community service activities for Bidikmisi students in the form of English language training activities are a problem-solving effort.

The following are the objectives of this activity: 
1. Encourage people to be interested in learning English and to be motivated to do so.

2. Providing Basic English Skills to Bidikmisi Students.

3. The following are the outcomes of this training activity:

4. Bidikmisi students' increased interest in learning English

5. Bidikmisi students' improved English skills

6. A boost in self-esteem as well as future competitiveness

\section{Implementation Method}

Bidikmisi's basic English training activities Students are placed in a study group with basic English subjects appropriate for their level, with a focus on students who need the greatest help with their English skills. The following are the stages of putting this Community Service program into action.

Bidikmisi pupils are the intended audience for the instruction. The Bidikmis Department and student organizations were informed of the training activities' socialization. An initial test is required prior to the implementation of the language training in order to assess the general capacity of Bidikmisi students. In addition to composing short essays in English, this first test uses a common question that can be used to analyze general English skills (the Nelson Quick Test). Because the training capacity is limited, training participants are chosen based on their ability levels' similarity, with a preference for those with the lowest abilities among others. Furthermore, one of the factors for ranking is the similarity of free hours to study English that does not conflict with the academic calendar of lectures.

Basic English training for Bidikmisi pupils necessitates the acquisition of basic English materials necessary for further study. Mastery of being, numbers, the alphabet, and many tenses, including Simple Present Tense, Simple Past Tense, and Present Continuous Tense, are among the materials covered. In terms of the method, one of them is thematically based, which entails information based on certain topics such as Introduction, Daily Schedule, and My Vacation.

Students are taught how to greet others, say the time, spell words, ask questions, and understand basic sentence patterns. Furthermore, students are driven to enhance their English skills because it is a requirement in the future, both in their careers and in high school.

Outside of the Pre-test and Post-test, Bidikmisi is scheduled for 12 meetings. On Tuesdays and Thursdays from 16.00-17.00, training activities are held in the afternoon after academic lecture activities.

The training teaching team consists of the entire Community Service Team, which includes two permanent English Lecturers with more than ten years of experience at IAI As'adiyah Sengkang. As a result, the training team is qualified to give Bidikmisi pupils training.

The evaluation is based on two factors: 
- The mastery of the material conveyed; and - the effectiveness of the material conveyed.

- The first data was obtained in the pretest for the basic general English questions as a Post-test.

\section{Results and Discussion}

\section{Interested in learning English}

There were 41 pupils present at the socialization stage for IAI As'adiyah Sengkang Bidikmisi students. They learned that Bidikmisi pupils will be receiving rudimentary English lessons. This is a big amount because the Bidikmisi path at IAI As'adiyah Sengkang only takes 30 or 40 students per academic year.

It was revealed that interested students should register with Bidikmisi Student Representatives and then participate in the September Pre-test/Placement Test program. After seeing the schedule of events for IAI As'adiyah Sengkang students, which was so crowded owing to the orientation period for majoring students, it was announced that an initial test for Bidikmisi pupils interested in attending Basic English Training would be held. The announcement was sent to all Bidikmisi students and copied to the department via the Bidikmisi student management.

Because some students have to participate in sports practice activities or orientation for the student association majors in the afternoon after regular lectures, the initial test for students is conducted in two terms. Despite the fact that there were only 43 registrants at the start, 53 students showed up to take the initial test. All persons present, however, are considered eligible to participate in these activities. The following information is provided to those who attended the Figure 1 training.

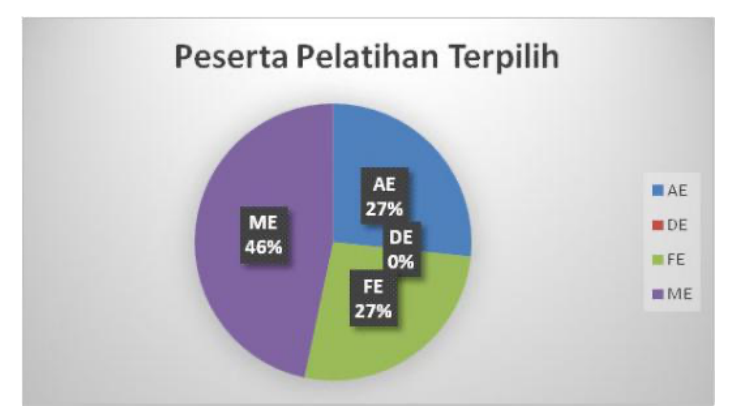

Figure 1. Interested in the Training

A total of 120 Bidikmisi Bachelor's degree pupils (up to level 3) have been documented. Pre-test activities were completed by 44.2 percent of Bidikmisi students. This also reveals that 44.2 percent of Bidikmisi students want to take part in basic English training activities. This number is quite high for students who have a full day of classes from dawn to evening (7.00-15.20). As a result, it can be concluded that Bidikmisi pupils are motivated to improve their English skills.

\section{Motivation to learn English}

Based on the results of the initial test, the score and level of students' English ability are announced, including the results of sorting the names of students who are entitled to take part in English training activities. In the announcement, 15 names were stated from various majors, the majority of which were Level 1 students. They were 
chosen because they had the lowest level of English. It is also stated that the study schedule is every Tuesday and Thursday from 16.00-17.00, which is located in the Theory Room, Building B (Tuesday) and the Lab. Language (Thursday). This announcement was also copied to the department and room manager.

Interests from one of the departments, namely Design Engineering, were not selected because, based on their level, the majority were not the most in need of training, and coincidentally, those with low abilities did not have a suitable schedule for participants to take part in training activities. At the first meeting of the training, 12 students were present. At the first meeting, in addition to receiving material 1, namely "Introduction", the participants were given information on the Basic English Learning/Training Syllabus, as well as the regulations, including informing the reasons for absence. Students look enthusiastic about learning.

At the second meeting, 13 students were present, which turned out to be the highest attendance during the training. Students learn material about the alphabet and spelling.

At the third meeting, only six participants were present. And for subsequent meetings, there were never more than nine people present. In the middle of the training period, many participants were unable to attend because there was an event with the student association where they were the participants, and the senior brother was on the committee. In addition, the reasons for illness and personal leave were also stated by the students. However, others did not state the reason for the absence. Indeed, the majority of the participants were level 1, so they felt it was more necessary to follow the rules of their seniors from the same major. The problem of motivation and discipline to keep learning turns out to need to be considered even more seriously.

The following is a graph of the attendance of the training participants in Figure 2.

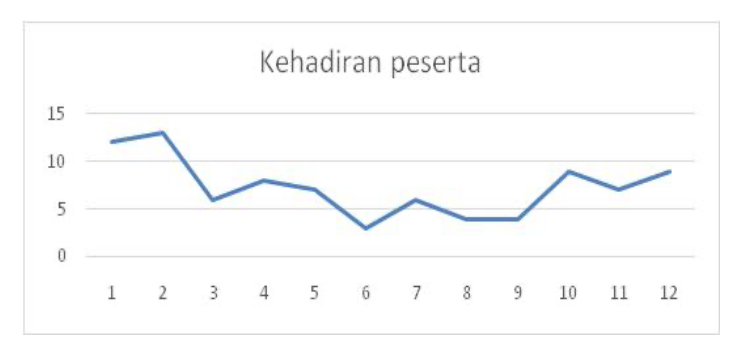

Figure 2. Trainee attendance chart

Only roughly 8-9 people appear to be more consistent in their desire to attend this basic English training, according to the attendance list. After then, there were eight people who took part in the post-test. Because the implementation of English language training for students appears to necessitate more binding regulations, it is preferable not to fill the position as a participant if students want to follow it but cannot follow the existing training regulations, so that it can be filled by other students who can meet the training regulations, especially when it comes to attendance issues. It's possible that in the future, instruction will be limited to students who have completed level 2. So that they can devote more time to their associations and majors. On the other hand, based on the input of the trainees, they concluded that mastering English language skills is necessary in order to confront future obstacles. 


\section{Changes in English Ability}

Eight participants provided data that could be used for an examination of the results of the Basic English skills improvement program at PPM.

If only the test questions from the English Language Standard Exam (Nelson test) are considered, their final score increased to 8.875 from 5.375 at the start (with a total of 25 questions). This indicates that their command of the English language improves. Figure 3 shows the pre-test and post-test scores of the individuals.

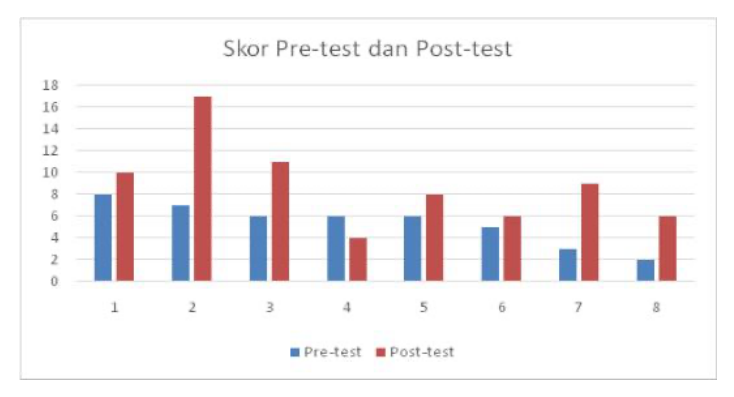

Figure 3. Pre-test and post-test scores of the individuals

Meanwhile, the average value of the test questions derived from the Training Materials is 74.5. (Scale 100). This shows that they grasp the training material at a 'Good' level. Trainee students must continue to study independently in order to improve and maintain their fundamental English skills. As a result, kids are able to follow English lessons without difficulty.

\section{Conclusions}

Several conclusions have been drawn from the implementation of this PKM in the form of Basic English Training for Bidikmisi students: Bidikmisi kids have generally responded positively to the PKM program. This is evidenced by the student's enthusiasm for the training program; the PKM program encourages students to enhance their English abilities after they realize how vital English is for their future. According to the results of the evaluation, students who participated in the Basic English Training improved their English skills. As a result, a program like this should be established to enable Bidikmisi pupils to compete effectively.

\section{Refereces}

Direkrorat Jenderal. (2017). Bantuan Biaya Pendidikan Bidikmisi Tahun 2017. Retrieved from http://www.unm.ac.id/AIPT/files/ok/3/4 PEDOMAN BIDIKMISI 2017.pdf

Fadhil, I., \& Sabic-El-Rayess, A. (2021). Providing equity of access to higher education in Indonesia: A policy evaluation. Indonesian Journal on Learning and Advanced Education (IJOLAE), 3(1), 57-75.

Febriana, M., Nurkamto, J., Rochsantiningsih, D., \& Muhtia, A. (2018). Teaching in rural Indonesian schools: Teachers' challenges. International Journal of Multicultural and Multireligious Understanding, 5(5), 11-20.

Hadisantosa, N. (2010). Insights from Indonesia. Learning through English: Policies, challenges and prospects, 24-46. 
Lamb, M., \& Coleman, H. (2008). Literacy in English and the transformation of self and society in post-Soeharto Indonesia. International journal of bilingual education and bilingualism, 11(2), 189-205.

Lamb, M. (2012). A self system perspective on young adolescents' motivation to learn English in urban and rural settings. Language learning, 62(4), 997-1023.

Lamb, M. (2013). 'Your mum and dad can't teach you!': constraints on agency among rural learners of English in the developing world.Journal of Multilingual and Multicultural Development, 34(1), 14-29.

Mudra, H. (2018). Pre-Service EFL Teachers' Experiences in Teaching Practicum in Rural Schools in Indonesia. Qualitative Report, 23(2).

Parlindungan, F., Rifai, I., \& Safriani, A. (2018). The representation of Indonesian cultural diversity in middle school English textbooks. Indonesian Journal of Applied Linguistics, 8(2), 289-302.

Pasassung, N. (2003). Teaching English in an" acquisition-poor environment": An ethnographic example of a remote Indonesian EFL classroom. Department of Linguistics, Faculty of Arts, University of Sydney.

Solikhah, I., \& Budiharso, T. (2019). Investigating the learning outcomes of an INQF-based English language teaching curriculum in Indonesia.Journal of Social Studies Education Research, 10(4), 153-175.

Suryadarma, D., \& Jones, G. W. (Eds.). (2013). Education in Indonesia. Institute of Southeast Asian Studies.

Wasahua, T., Koesmaryono, Y., \& Sailah, I. (2018). Evaluation Policy on Assistance Program Bidikmisi Higher Education in Private Kopertis Region XII. Journal of Education and e-Learning Research, 5(1), 1-7.

Zein, M. S. (2017). Elementary English education in Indonesia: Policy developments, current practices, and future prospects: How has Indonesia coped with the demand for teaching English in schools?. English Today, 33(1), 53-59. 